
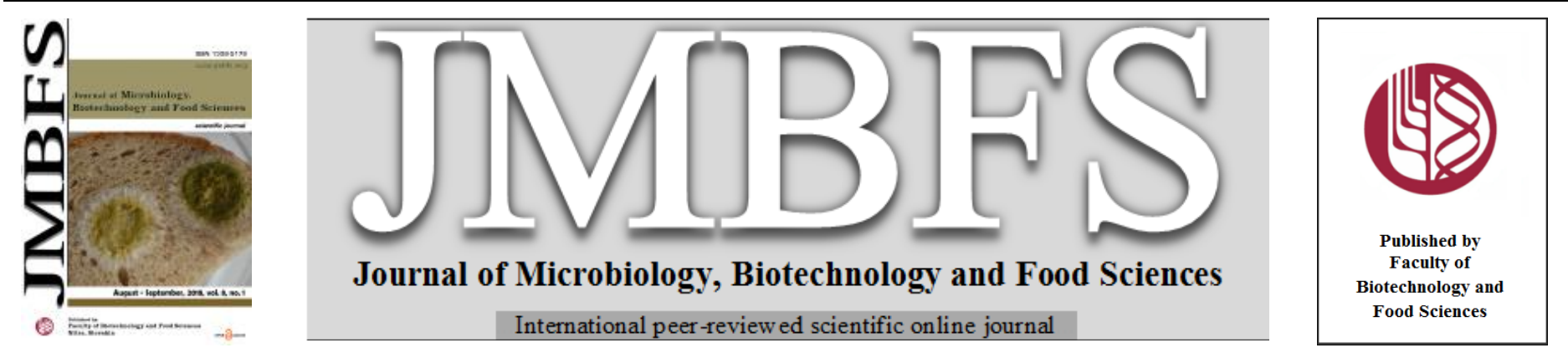

\title{
COMPARISON OF THE ANTIOXIDANT AND PHYTOCHEMICAL PROPERTIES OF DAWADAWA (SUB-SAHARA AFRICA CONDIMENT) FROM MUCUNA PRURIENS L. AND PARKIA BIGLOBOSA Jacg. UNDER CONTROL CONDITION
}

\section{Ruth. A. O. Gabriel-Ajobiewe ${ }^{I^{*}}$, Beatrice O.T. Ifesan ${ }^{2}$ and Olajumoke M. Ayoko ${ }^{2}$}

\author{
$\operatorname{Address(es):~}$ \\ ${ }^{1}$ Department of Department of Microbiology, Faculty of Science, Federal University Oye-Ekiti, Nigeria. \\ ${ }^{2}$ Department of Food Science and Technology, School of Agriculture, Federal University of Technology Akure, Nigeria.
}

*Corresponding author: adefolakemi.gabriel-ajobiewe@fuoye.edu.ng

doi: $10.15414 / j m b f s .2018 .8 .1 .705-710$

ARTICLE INFO

Received 18. 3. 2018

Revised 15. 5. 2018

Accepted 3. 7. 2018

Published 1. 8. 2018

Regular article

open $\odot$ access

\begin{abstract}
The ethnopharmacological relevance of Mucuna pruriens (Linn) with its' nutrients content present itself as an option in functional food. This study evaluated the antioxidant and phytochemical properties of Bacillus subtilis fermented condiment (dawadawa) from Mucuna pruriens in comparison with Parkia biglobosa using dehulled, thermally treated seeds. The phytochemicals decreased with increase in pressured cooking time; with the condiment of Parkia having higher significant difference. The total phenol, vitamin $\mathrm{C}$ and total flavonoid (TF) content for Mucuna (123.34 mg/g; vit C- $0.72 \pm 0.04 \mathrm{mg} / \mathrm{g}$; TF-22.21 $\pm 0.23 \mathrm{mg} / \mathrm{g}$ ) were significantly higher than Parkia's. The FRAP and ABTS scavenging ability of Parkia decreased with cooking time, while that of Mucuna $(34.33 \pm 1.49 \mathrm{mg} / \mathrm{g}$ and $98.33 \pm 1.39 \mathrm{milimol} / \mathrm{g})$ was increasing. Fermented Мисипа (50.73\%) demonstrated higher ability to scavenge 1, 1- diphenyl-2-picryhydrazylradicals. Result obtained suggested that fermented Muсuna may produce valuable contribution to health as an antioxidant in comparison to fermented Parkia as nutraceutical.
\end{abstract}

Keywords: antioxidant, condiment, nutraceutical, Mucuna pruriens, phytochemical

\section{INTRODUCTION}

Many of the known wild and underutilized legumes (such as Mucuna spp. ,Canavalia spp., Sesbania spp., etc.) possess adequate amounts of protein, essential amino acids, polyunsaturated fatty acids (PUFAs), dietary fiber, essential minerals and vitamins along with the presence of beneficial bioactive compounds when comparable to other common legumes (Bhat and Karim, 2009). Mucuna pruriens (M. pruriens), a leguminous plant, is identified as an herbal medicine for improving the fertility and related disorders in the Indian traditional system of medicine, however without any scientific validations. All part of Mucuna plants are known to possess high medicinal value. The seeds have been known to contain many pharmaceutical with antiepileptic and anti-neoplastic activities. It also possesses anti-parkinsonian activities, anti-inflammatory, antispasmodic, anti-vemin, anabolic, androgenic, analgesic, aphrodisiac, (Guerranti et al., 2002). Raw Mucuna bean seed is known to contain anti-nutritional/toxic factors such as trypsin inhibitors, tannins and cyanide. The presence of Dopa (a potentially neurotoxic agent) in the raw bean has also been reported (Siddhuraju et al., 1996). The plant is rich in alkaloids such as prurienine, prurieninine and prurienidine (Misra and Wagner, 2007). Triterpenes and sterols (-sitosterol, ursolic acid, etc.) are found in the root and seeds of $M$. pruriens. The seeds also contain amino acids methionine, tyrosine, lysine, glycine, aspartic acid, glutamic acid, leucine and serine along with globulins and albumins, fatty acids, carbohydrates, and related compounds such as oleic acid, linoleic acid and palmitic acid (Adebowale $\boldsymbol{e t}$ al., 2005).

The anti-nutritional toxic factor has to be decreased to safe level either by boiling, heating or fermentation before the inclusion of any of the unconventional legumes in livestock rations (Josephine and Janardhanan, 1992). Another method of improving nutritional quality of legumes is fermentation. Food fermentation is a microbial and enzymatic method for food processing to achieve prolonged shelflife. Oil seeds such as African locust bean, melon seed, castor oil seed, mesquite seed and soybean are also fermented to produce condiments. African locust bean tree Parkia biglobosa is widely recognized in West Africa as an important multipurpose tree of West Africa Savannah land. The most important part of the tree is found in its seeds and the processed seed is used as condiment for soup. It is a source of natural nutritious condiment which features frequently in the traditional diet of the people (Fagbemi, 1989). Food condiments or spices are strong-smelling, sharp tasting substances usually used to improve or adjust the flavour of food. They are usually of vegetable origin which common examples include mustard, nutmeg, ginger, garlic, coriander, locust bean. Alkaline fermentations cause the hydrolysis of protein to amino acids and peptides and releasing ammonia, which increases the alkalinity by the Bacillus species such as Bacillus subtilis (dominant species), B. licheniformis and B. pumilus (Enujiugha et al., 2008; Chelule et al., 2010). Bacillus subtilis is a strongly proteolytic bacterium which is mainly used in alkaline fermentation of legumes such as soybean. It causes biochemical changes in beans by hydrolysis of proteins and metabolism of resultant amino acids leading to increase in $\mathrm{pH}$ and flavour development. In order to improve nutritional quality, and effective utilization of dry legumes to their full potential as food, inactivation or removal of antinutritional factors by adopting economically viable processing techniques is necessary. Mucuna pruriens been reported as a high proteineous crop than most commonly consumed legumes content with a ranges of 23 to $35 \%$. Therefore this study is undertaken to investigate the possibility of using Mucuna pruriens as an alternative to Parkia biglobosa seed for the production of condiments. Also to assess the quality of condiments produced from the two beans using starter culture of Bacillus subtilis 7A and BCD 333.

\section{MATERIALS AND METHODS}

\section{Sample collection}

The velvet beans (Mucuna pruriens) and locust beans (Parkia biglobosa) used for this study were purchased from a research institute (IITA) in Ibadan, Oyo State and open market in Akure, Ondo State, Nigeria respectively. All reagents used for the analysis were of analytical grade.

\section{Preparation of samples}

\section{Harvest of microbial cells}

Two strains of Bacillus subtilis (7A and BCD 333) selected based on favourable morphological, biochemical characteristics and dominance after fermentation were maintained on broths and slants (Aderibigbe et al., 2011). Fresh cell cultures of Bacillus subtilis (7A and BCD 333) isolates which were activated overnight in nutrient agar respectively were harvested in graduated sterilized Eppendorf tubes of $5 \mathrm{ml}$ using a micro centrifuge (Stuart microfuge SRFC1 $10000 \mathrm{X} \mathrm{rpm}$ ) at 
$6000 \mathrm{rpm}$ for $5 \mathrm{~min}$. After centrifuging the supernatants were decanted using micropipette and sterilized tips. The cell pellets at the bottom of the tubes were rinsed with $1000 \mu \mathrm{l}$ sterile DNA free water, centrifugation was repeated at 6000 rpm for $3 \mathrm{~min}$. After which the supernatants were decanted and the cell pellets were made up with $1000 \mu \mathrm{l}$ of sterile DNA free water to obtain pure strains cells. The harvested cells were maintained on ice prior to usage.

\section{Production of fermented beans from Parkia biglobosa and Mucuna pruriens}

The modified method of Gabriel et al., (2004) was employed. The locust and velvet beans seeds were sorted to remove dirt, stones and foreign materials. The locust beans were cooked for $2 \mathrm{~h}$ after which they were dehulled using mortar and pestle and washed in clean water until all the hulls have been removed. Alternatively, the velvet seeds were soaked in hot water for ten min and thereafter, dehulled manually. The dehulled seeds of each beans were then divided into three portions; the first portion was not pressure cooked after dehulling, while the remaining two portions were pressure cooked for $15 \mathrm{~min}$ and $30 \mathrm{~min}$ respectively. The uncooked dehulled sample was soaked in $10 \%$ hypochlorite to make it sterile after which, it was aseptically transferred into a sterile foil plate and the inoculum was added to it under aseptic conditions. The remaining two pressured-cooked portions were also transferred aseptically into sterile foil plate after which, the inoculums (Bacillus subtilis 7A and BCD 333) used were added respectively and these were kept in plastic buckets and fermented at $35{ }^{\circ} \mathrm{C}$ inside an incubator respectively for $36 \mathrm{hr}$. The resulting fermented seeds were dried in an oven (PEC North America, Boca Raton, FL 33431, USA) at $60{ }^{\circ} \mathrm{C}$ for $6 \mathrm{~h}$. It was then milled and stored for analysis.

\section{Determination of total viable microbial count of fermenting beans}

Ten grams of fermented seeds was homogenized with $0.1 \%$ sterile peptone water (Biolab Zrt., Hungary) in sterile Ziploc bag working under aseptic condition and serial dilution was performed. One milliliter of diluents five and six were aseptically dispensed into sterile Petri dish with sterilized Nutrient agar (Lab M, Lancashire BL9 7JJ, United Kingdom) added and swirled for proper mixing. It was allowed to solidified and incubated at $37^{\circ} \mathrm{C}$ for $18 \mathrm{~h}$. The total viable count during the fermentation period was determined with the help of a colony counter (Deihan Labtech, New Delhi-110008, India) and the colony forming unit (cfu) calculated, This was done at every $12 \mathrm{~h}$ interval throughout the $36 \mathrm{~h}$ of fermentation time.

\section{Physicochemical analyses of fermented velvet and locust beans}

The $\mathrm{pH}$ of the samples was determined at every $12 \mathrm{~h}$ interval throughout the fermentation period of $36 \mathrm{~h}$. Two gram of homogenized fermenting beans was taken using a $\mathrm{pH}$ meter (Model 401).

The amount of lactic acid in the fermenting mass was determined by titration of 20 $\mathrm{ml}$ filtrate obtained from $2 \mathrm{~g}$ of fermenting seeds dissolved in $20 \mathrm{ml}$ distilled water against $0.1 \mathrm{M} \mathrm{NaOH}$ using phenolphthalein as indicator. The titre value was then used to calculate the titratable acidity as percentage lactic acid (AOAC, 2010).

\section{Determination of phytochemical composition of fermented velvet and locust} beans

Oxalate was determined according to the titration method of Day and Underwood, (1986). $1 \mathrm{~g}$ of sample was weighed into $100 \mathrm{ml}$ conical flask. $75 \mathrm{ml} 3 \mathrm{MH} 2 \mathrm{SO} 4$ was added and stirred for $1 \mathrm{hr}$ with a magnetic stirrer. $25 \mathrm{ml}$ of the filtrate was then taken and titrated while hot against $0.05 \mathrm{M} \mathrm{KMnO} 4$ solution until a faint pink colour persisted for at least $30 \mathrm{sec}$. The oxalate content was then calculated by taking $1 \mathrm{ml}$ of $0.05 \mathrm{~m} \mathrm{KMnO} 4$ as equivalent to $2.2 \mathrm{mg}$ oxalate.

The spectrophotometric method of Brunner, (1984) was used for saponin quantification. Two gram of the finely grinded sample was weighed into a $250 \mathrm{~mL}$ beaker and $100 \mathrm{~mL}$ of Isobutyl alcohol was added, the mixture was shaked in the Shaker for $5 \mathrm{~h}$ to ensure uniform mixing. The mixture was filtered into $100 \mathrm{~mL}$ beaker containing $20 \mathrm{~mL}$ of $40 \%$ saturated solution of magnesium carbonate. The mixture obtained again was filtered to obtain a clean colourless solution. One milliliter was added into $50 \mathrm{~mL}$ volumetric flask using pipette, $2 \mathrm{~mL}$ of $5 \%$ iron (iii) chloride $\left(\mathrm{FeCl}_{3}\right)$ solution was added and made up to the mark with distill water. It was allowed to stand for $30 \mathrm{~min}$ for the colour to develop. The absorbance was read against the blank at $380 \mathrm{~nm}$ :

Phytate was determined according to the method of Okon and Akpanyung (2005). $100 \mathrm{ml}$ of the sample was extracted with $3 \%$ trichloroacetic acid. The extract was treated with $\mathrm{FeCl} 3$ solution and the iron content of the precipitate was determined using Atomic Absorption spectrophotometer (Cye Unicam 2900). A $4: 6 \mathrm{Fe} / \mathrm{P}$ atomic ratio was used to calculate the phytic acid content.

Trypsin inhibitor activity (TIA) was determined by the method of Kakade $\boldsymbol{e t}$ al., (1974) using benzoyl-DL-arginine-p-nitroanilide (BAPNA) as substrate Absorbance (A) was read at $410 \mathrm{~nm}$ wavelength. Trypsin inhibitory activity was defined as the number of trypsin inhibitor units (TIU). One TIU was defined as an increase of 0.01 in absorbance units under conditions of assay.

Tannin was determined according to the method of Makkar (1999). Exactly $2.0 \mathrm{~g}$ of sample was added to $20 \mathrm{~mL}$ of $50 \%$ methanol and placed in a water bath at $77^{\circ} \mathrm{C}$ $-80^{\circ} \mathrm{C}$ for $1 \mathrm{hr}$ and shaken. The extract was quantitatively filtered using a double layered Whatman No.1 filter paper and $20 \mathrm{~mL}$ of distilled water, $2.5 \mathrm{~mL}$ FolinDenis reagent and $10 \mathrm{~mL} 17 \% \mathrm{Na} 2 \mathrm{CO} 3$ were added and mixed. The mixture was allowed to stand for $20 \mathrm{~min}$. The bluish-green colour developed at the end of the treatment on the range $0-10 \mathrm{ppm}$. The absorbance of the tannic acid standard solutions as well as samples was read after colour development on a spectronic 21D spectrophotometer at a wavelength of $760 \mathrm{~nm}$ against a reagent blank concentration of the same solution from a standard tannic acid curve prepared. Percentage tannin was calculated.

\section{Determination of antioxidant properties of fermented velvet and locust bean}

For evaluation of antioxidant activity of the fermented flours, all tests were carried out in triplicate. The extraction technique of Oboh et al, (2007) was used to collect supernatant from $1.0 \mathrm{~g}$ of each fermented sample using the rotary shaker (Centurium Scientific, United Kingdom) at $190 \mathrm{rpm}-220 \mathrm{rpm}$ for $3 \mathrm{~h}$, filtered, and centrifuged (Centurium Scientific, United Kingdom) at $5000 \mathrm{rpm}$ for $15 \mathrm{~min}$.

This was used in antioxidant measurements and determination of total phenolic (Singleton et al., 1999). The reaction mixture composed of $0.5 \mathrm{ml}$ of methanolic solution of extract, $2.5 \mathrm{ml}$ of $10 \%$ Folin-Ciocalteu's reagent dissolved in water and $2.5 \mathrm{ml} \mathrm{7.5 \%} \mathrm{NaHCO3}$. The blank contained $0.5 \mathrm{ml}$ methanol, $2.5 \mathrm{ml} 10 \%$ FolinCiocalteu's reagent dissolved in water and $2.5 \mathrm{ml}$ of $7.5 \%$ of $\mathrm{NaHCO} 3$. The samples were thereafter incubated in a thermostat at $45 \mathrm{oC}$ for $45 \mathrm{~min}$ and absorbance taken at $765 \mathrm{~nm}$ using spectrophotometer. The samples were prepared in triplicate for each analysis and the mean value of absorbance was obtained Gallic acid was used as the standard solution and calibration line was construed. Based on the measured absorbance, the concentration of phenolics was read $(\mathrm{mg} / \mathrm{ml})$ from the calibration line; then the content of phenolics in extracts was expressed in terms of gallic acid equivalent (mg of GA/g of extract).

The flavonoid contents (Bushra et al., 2009) modified by incubating at room temperature for $30 \mathrm{~min}$. Extracts were diluted with water in a $10 \mathrm{ml}$ volumetric flask. Initially, 5\% NaNO2 solution was added to each volumetric flask; at $5 \mathrm{~min}$, $10 \% \mathrm{AlCl} 3$ was added; and at $6 \mathrm{~min}, 1.0 \mathrm{M} \mathrm{NaOH}$ was added. Water was then added to the reaction flask and mixed well. Absorbance of the reaction mixture was read at $430 \mathrm{~nm}$. The results were expressed in $\mathrm{mg}$ quercetin/g DW by comparison with the quercetin standard curve, which was made in the same condition.

Ferric reducing antioxidant power (FRAP) assay was determined according to the method of Oyaizu, (1986) and the absorbance read at $700 \mathrm{~nm}$ in UV-Visible spectrophotometer (PG Instruments, Leicestershire LE17 5BH, United Kingdom). The sample extracts of varying concentration $(20-100 \mu \mathrm{g})$ were taken in $1 \mathrm{~mL}$ of phosphate buffer in a test tube and $5 \mathrm{~mL}$ of $0.2 \mathrm{M}$ phosphate buffer, $\mathrm{pH} 6.6$ was added. To this, $5 \mathrm{~mL}$ of $1 \%$ potassium ferricyanide solution was added. The mixture was incubated at $50{ }^{\circ} \mathrm{C}$ for $20 \mathrm{~min}$. After the incubation, $5 \mathrm{~mL}$ of $10 \%$ TCA was added and the content was centrifuged at $1,000 \mathrm{rpm}$ for $10 \mathrm{~min}$. The upper layer of the supernatant $(5 \mathrm{~mL})$ was mixed with $5 \mathrm{~mL}$ of distilled water. To this, $1 \mathrm{~mL}$ of ferric chloride $(0.1 \%)$ was added and vortexed. Then, the absorbance of the reaction mixture was read spectrophotometrically at $700 \mathrm{~nm}$ against water blank.

The spectrometric assay uses the stable radical 2, 2-diphenyl-1-picryl-hydrazyl (DPPH) as a reagent (Butrits and Bucar, 2000) by the hydrogen atom or electrons donating ability of the fermented beans sample. Alcohol solution of DPPH (3 ml) was added to $1 \mathrm{ml}$ samples containing different concentrations originating from the extracts. The samples were first kept in a dark place at room temperature and their absorbance was read at $518 \mathrm{~nm}$ after $30 \mathrm{~min}$. The antiradical activity (AA) was determined using the below formula: AA\% $=(($ Absorbance sample-Absorbance empty sample $) \times 100$ )/Absorbance control Blank samples contained $1 \mathrm{ml}$ ethanol + $2.5 \mathrm{ml}$ from various concentrations of plant extract. Control sample containing 1 $\mathrm{ml}$ of $0.3 \mathrm{mM}$ DPPH $+2.5 \mathrm{ml}$ ethanol. The optic density of the samples, the control and the empty samples were measured in comparison with ethanol. BHT (butylhydroxytoluene) and $\alpha$-tocopherol were used as positive controls.

Ascorbic acid (Vitamin $\quad$ C) content was analyzed by the modified spectrophotometric method described by Güçlü et al., (2005). The method used is based on the oxidation of Ascorbic acid to dehydroascorbic acid with a $\mathrm{Cu}$ (II)-Nc reagent in an ammonium acetate-containing medium at $\mathrm{pH} 7.0$, where the maximum absorption wavelength of the formed bis-(neocuproine) copper(I) chelate is $450 \mathrm{~nm}$. One $\mathrm{mL}$ of $\mathrm{CuCl} 2$ solution was placed in a test tube, and then 1 $\mathrm{mL}$ of $\mathrm{Nc}$, and $1 \mathrm{~mL}$ ammonium acetate to bring the final $\mathrm{pH}$ to $7.0 ; 1.4 \mathrm{~mL}$ of water and $0.6 \mathrm{~mL}$ Ascorbic acid solution were finally added by mixing in this order. After $2 \mathrm{~min}$, the absorbance at $450 \mathrm{~nm}$ was recorded against a reagent blank. The 2, 2'-Azino-bis (3-ethylbenzothiazoline-6-sulfonic) acid (ABTS) antioxidant activity was assayed on the basis of a protocol represented by Re $\boldsymbol{e t}$ al., (1999) spectrophotometrically at a wave length of $734 \mathrm{~nm}$. The percentage of the radical scavenging capacity was determined. ABTS was dissolved in water to a $7 \mathrm{mM}$ concentration. ABTS radical cation was produced by reacting ABTS stock solution with $2.45 \mathrm{mM}$ potassium persulfate (final concentration) and allowing the mixture to stand in the dark at room temperature for $12-16 \mathrm{~h}$ before use. Prior to assay, the solution was diluted in ethanol (about $1: 89 \mathrm{v} / \mathrm{v}$ ) and equilibrated to $30^{\circ} \mathrm{C}$ to give an absorbance at $734 \mathrm{~nm}$ of $0.700 \pm 0.02$ in a $1 \mathrm{~cm}$ cuvette. The concentration of sample extract that produced between $20 \%$ and $80 \%$ inhibition of the blank 
absorbance was determined and adapted. Triplicate determinations were made at each dilution of the standard, and the percentage inhibition of the blank absorbance at $734 \mathrm{~nm}$ was plotted as a function of Trolox concentration. The unit of tota antioxidant activity (TAA) was defined as the concentration of Trolox having equivalent antioxidant activity expressed as $\mu \mathrm{mol} / \mathrm{g}$ sample extracts on dry matter basis.

\section{RESULTS AND DISCUSSION}

Total viable counts of bacteria in locust and velvet beans during fermentation

Table 1 showed the microbial load of the fermented locust beans and velvet beans that there were variations in total microbial counts based on cooking time and duration of fermentation. For fermented locust beans, cooking reduced microbial loads for samples fermented at both $12 \mathrm{~h}$ and $24 \mathrm{~h}$. However, highest is 0.95 $\times 10^{9} \mathrm{cfu} / \mathrm{ml}$ at $24 \mathrm{~h}$ of fermentation and $4.9 \times 10^{8} \mathrm{cfu} / \mathrm{ml}$ was observed in locust beans cooked for $30 \mathrm{~min}$ and fermented for $36 \mathrm{~h}$. Increase in microbial load was observed at $12 \mathrm{~h}$ and $24 \mathrm{~h}$ of fermentation for uncooked fermented velvet and fermented velvet beans cooked for $15 \mathrm{~min}$. Lowest microbial load of $0.6 \times 109$ $\mathrm{cfu} / \mathrm{ml}$ was observed in velvet beans cooked for $30 \mathrm{~min}$ and fermented for $24 \mathrm{~h}$.

Table 1 Total microbial counts of locust and velvet beans fermented at $35^{\circ} \mathrm{C}$.

\begin{tabular}{lccc}
\hline Samples & $\mathbf{1 2 ~ h} \mathbf{( c f u / m l )}$ & $\mathbf{2 4} \mathbf{~ h}(\mathbf{c f u} / \mathbf{m l})$ & $\mathbf{3 6 ~ h} \mathbf{( c f u} / \mathbf{m l})$ \\
\hline LBO & $1.74 \times 10^{9}$ & $1.13 \times 10^{9}$ & $4.25 \times 10^{8}$ \\
LB15 & $1.3 \times 10^{8}$ & $0.8 \times 10^{9}$ & $1.15 \times 10^{8}$ \\
LB30 & $0.6 \times 10^{8}$ & $0.95 \times 10^{9}$ & $4.9 \times 10^{8}$ \\
VBO & $1.04 \times 10^{9}$ & $4.25 \times 10^{8}$ & $1.5 \times 10^{8}$ \\
VB15 & $0.7 \times 10^{8}$ & $4.75 \times 10^{8}$ & $1.5 \times 10^{8}$ \\
VB30 & $3.8 \times 10^{8}$ & $0.6 \times 10^{9}$ & $1.2 \times 10^{9}$ \\
\hline Values are expressed as means \pm standard deviation on a dry weight basis.
\end{tabular}

Legends: LB0 - Locust beans cooked for 0 min, LB15 - Locust beans cooked for $15 \mathrm{~min}$, LB30 - Locust beans cooked for $30 \mathrm{~min}$,

VB0 - Velvet beans cooked for $0 \mathrm{~min}, \mathrm{VB} 15$ - Velvet beans cooked for $15 \mathrm{~min}$, VB30 - Velvet beans cooked for $30 \mathrm{~min}$

From the revelation of the result in Table 1, there was initial increase in the total viable count of bacteria in some of the samples both pressure cooked and uncooked within the $24 \mathrm{~h}$ of fermentation after which it started fluctuating. This could be as a result of the change in the growth of microorganism as fermentation progressed. Similar results were observed during fermentation of African oil bean seeds as reported by Enujiugha et al., (2008). Babalola and Giwa, (2012) reported increase in microbial load of cooked soybeans after $24 \mathrm{~h}$ of fermentation. This observation is also in agreement with the results obtained by David and Aderibigbe, (2010) during microbiological examination of ogiri. The decline and fluctuation in microbial loads of some samples could be as a result of depletion of nutrient in the fermenting medium which led to competition for survival among the organisms. On the other hand, initial increase in microbial load at the start of fermentation could be associated with the fact that, the microbes are in there stationary phase, thereby, the available nutrients encouraged their growth (Babalola and Giwa, 2012).

\section{Physicochemical analyses of condiments from locust and velvet beans}

The $\mathrm{pH}$ of the fermented legumes (cooked and uncooked) increased as cooking time and hour of fermentation increased. Samples cooked for $30 \mathrm{~min}$ had the highest value of 6.5 and 6.05 for locust beans and velvet beans at $12 \mathrm{~h}$ of fermentation respectively. Similar trend was observed at $24 \mathrm{~h}$ and $36 \mathrm{~h}$ of fermentation. In all instances, for both fermented legumes, high level of $\mathrm{pH}$ was observed at cooking time of $30 \mathrm{~min}$ (Table 2).

Results of total titratable acidity of fermented locust beans and velvet beans are show in Table 2. In all the samples, it was observed that TTA decreased as hour of fermentation increased. Total titratable acidity level of uncooked fermented locust beans decreased from 8.6 to 5.04 at $36 \mathrm{~h}$ of fermentation. Similar trend was observed for uncooked fermented velvet beans which have a value of $6.87 \%$ at 36 $\mathrm{h}$ of fermentation. At $12 \mathrm{~h}$ of fermentation, fermented locust beans cooked for 15 min had the highest titratable acidity of $15.42 \%$.

As shown in Table 2, it was observed that there was increase in $\mathrm{pH}$ value of locust beans and velvet beans during the course of fermentation. This observation is similar to the finding of Egounlety, (2003) who noticed increase in the level of $\mathrm{pH}$ of Mucuna tempe and Mucuna condiment after $48 \mathrm{~h}$ of fermentation and the increase was attributed to protein hydrolysis during fermentation. Increase in $\mathrm{pH}$ during fermentation of protein-rich oil seeds has also been reported by severa authors (David and Aderibigbe, 2010; Babalola and Giwa, 2012). Increase in $\mathrm{pH}$ during fermentation has also been attributed to proteolytic activities and the release of ammonia following the utilization of amino acids by microorganisms involved in the fermentation (Sarkar $\boldsymbol{e t}$ al., 1993). Ammonia is mainly responsible for the characteristic pungent smell that usually accompanies most vegetative protein fermentation. The Table also revealed that there was decrease in titratable acidity (TTA) of samples of condiments from fermented locust and velvet beans, as fermentation progressed. This is an indication that less of organic acids production and more of proteinase activity occurred during fermentation (Nout, 1994).

Table 2 Physicochemical parameters [pH and total titratable acidity (TTA)] of locust and velvet beans fermented at $35^{\circ} \mathrm{C}$

\begin{tabular}{lrccc}
\hline Samples & 12h & $\mathbf{2 4 h}$ & $\mathbf{3 0 h}$ & $\mathbf{3 6 h}$ \\
\hline pH & & & & \\
\hline LB0 & $5.92 \pm 0.02^{\mathrm{b}}$ & $6.16 \pm 0.01^{\mathrm{c}}$ & $6.48 \pm 0.03^{\mathrm{c}}$ & $6.83 \pm 0.03^{\mathrm{c}}$ \\
LB15 & $6.20 \pm 0.00^{\mathrm{d}}$ & $6.30 \pm 0.02^{\mathrm{d}}$ & $6.52 \pm 0.01^{\mathrm{c}}$ & $6.80 \pm 0.00^{\mathrm{c}}$ \\
LB30 & $6.50 \pm 0.04^{\mathrm{e}}$ & $7.10 \pm 0.00^{\mathrm{e}}$ & $7.18 \pm 0.01^{\mathrm{d}}$ & $7.30 \pm 0.00^{\mathrm{d}}$ \\
VB0 & $5.33 \pm 0.03^{\mathrm{a}}$ & $5.40 \pm 0.02^{\mathrm{a}}$ & $5.54 \pm 0.00^{\mathrm{a}}$ & $5.72 \pm 0.00^{\mathrm{a}}$ \\
VB15 & $6.05 \pm 0.05^{\mathrm{c}}$ & $6.05 \pm 0.00^{\mathrm{b}}$ & $6.13 \pm 0.01^{\mathrm{b}}$ & $6.25 \pm 0.00^{\mathrm{b}}$ \\
VB30 & $6.05 \pm 0.00^{\mathrm{c}}$ & $6.08 \pm 0.00^{\mathrm{b}}$ & $6.14 \pm 0.02^{\mathrm{b}}$ & $6.20 \pm 0.00^{\mathrm{b}}$ \\
Total titratable acidity & & & \\
\hline LB0 & $8.60 \pm 0.04^{\mathrm{b}}$ & $7.85 \pm 0.05^{\mathrm{c}}$ & $6.52 \pm 0.02^{\mathrm{b}}$ & $5.04 \pm 0.02^{\mathrm{b}}$ \\
LB15 & $15.42 \pm 0.04^{\mathrm{e}}$ & $8.37 \pm 0.03^{\mathrm{d}}$ & $7.13 \pm 0.01^{\mathrm{c}}$ & $6.17 \pm 0.01^{\mathrm{c}}$ \\
LB30 & $7.32 \pm 0.02^{\mathrm{a}}$ & $5.33 \pm 0.03^{\mathrm{a}}$ & $4.67 \pm 0.03^{\mathrm{a}}$ & $3.65 \pm 0.03^{\mathrm{a}}$ \\
VB0 & $7.06 \pm 0.01^{\mathrm{a}}$ & $7.02 \pm 0.02^{\mathrm{b}}$ & $6.92 \pm 0.01^{\mathrm{c}}$ & $6.87 \pm 0.03^{\mathrm{d}}$ \\
VB15 & $9.12 \pm 0.01^{\mathrm{c}}$ & $7.95 \pm 0.05^{\mathrm{c}}$ & $7.67 \pm 0.03^{\mathrm{d}}$ & $7.32 \pm 0.02^{\mathrm{e}}$ \\
VB30 & $10.12 \pm 0.02^{\mathrm{d}}$ & $9.02 \pm 0.02^{\mathrm{e}}$ & $7.97 \pm 0.01^{\mathrm{de}}$ & $6.31 \pm 0.01^{\mathrm{c}}$ \\
\hline
\end{tabular}

Values are expressed as means \pm standard deviation on a dry weight basis. Means of triplicate determinations \pm S.D.

Means with different superscripts on the same column are significantly different at $p \leq 0.05$

Legends: LB0 - Locust beans cooked for 0 min, LB15 - Locust beans cooked for 15 min, LB30 - Locust beans cooked for $30 \mathrm{~min}$

VB0 - Velvet beans cooked for 0 min, VB15 - Velvet beans cooked for $15 \mathrm{~min}$, VB30 - Velvet beans cooked for $30 \mathrm{~min}$.

Phytochemical composition of condiments from fermented locust and velvet beans

The results of the effect of increase in cooking duration and fermentation with Bacillus subtilis, on the levels of some anti-nutritional factors of African locust beans and velvet beans are given in Table 3. Oxalate levels of the samples were significantly different $(\mathrm{p} \leq 0.05)$ with uncooked fermented locust beans having the highest value of $0.69 \mathrm{mg} / \mathrm{g}$. There was no significant difference $(\mathrm{p} \geq 0.05)$ in the saponin level of fermented locust beans and fermented velvet beans at the same cooking time. Phytate level of fermented locust beans decreased from $28.83 \mathrm{mg} / \mathrm{g}$ to $25.42 \mathrm{mg} / \mathrm{g}$ at $30 \mathrm{~min}$ cooking time. Similar trend was observed for phytate level of fermented velvet beans. The values obtained for trypsin inhibitor were all significantly different $(\mathrm{p} \leq 0.05)$ with the exception of uncooked fermented locust beans and locust fermented after $15 \mathrm{~min}$ of cooking. There was decrease in the level of tannin as cooking time progressed, tannin decreased from $4.46 \mathrm{mg} / 100 \mathrm{~g}$ to $3.49 \mathrm{mg} / 100 \mathrm{~g}$ in fermented locust beans and $8.46 \mathrm{mg} / 100 \mathrm{~g}$ to $8.08 \mathrm{mg} / 100 \mathrm{~g}$ in fermented velvet beans.

The level of phytochemical constituent in locust beans and velvet beans, as influenced by cooking and fermentation was shown (Table 3 to decreased significantly $(\mathrm{p} \leq 0.05)$ with increase in the duration of cooking. This finding supports the report of Ezeagu et al., (2003). Some microorganisms have been reported to possess enzymes that are capable of hydrolyzing anti-nutrients (Gabrie et al., 2004). Oxalate content of the samples was influenced by cooking as the values lowered at specified cooking durations. This observation is in agreement with the finding of Iorgyer et al., (2009) on reduction of oxalate of pigeon pea seeds. The level of phytate in fermented locust and velvet beans was found to reduce with increase in the duration of cooking and fermentation. Several authors have reported similar observation in this regard (Siddhuraju et al., 1996; Mugendi et al., 2010) noticed that roasting, germination and fermentation reduced level of phytate in Mucuna beans. 
Table 3 Phytochemical composition of condiments from locust and velvet beans fermented at $35^{\circ} \mathrm{C}$

\begin{tabular}{llllll}
\hline Samples & $\begin{array}{l}\text { Oxalate } \\
(\mathbf{m g} / \mathbf{g})\end{array}$ & $\begin{array}{l}\text { Saponin } \\
(\mathbf{m g} / \mathbf{1 0 0} \mathbf{g})\end{array}$ & $\begin{array}{l}\text { Phytate } \\
(\mathbf{m g} / \mathbf{g})\end{array}$ & $\begin{array}{l}\text { Trypsin Inhibitor } \\
\text { Activity }(\mathbf{m g} / \mathbf{g})\end{array}$ & $\begin{array}{l}\text { Tannin } \\
(\mathbf{m g} / \mathbf{1 0 0} \mathbf{g})\end{array}$ \\
\hline LBO & $0.69 \pm 0.00^{\mathrm{a}}$ & $0.91 \pm 0.00^{\mathrm{a}}$ & $28.83 \pm 0.02^{\mathrm{b}}$ & $3.60 \pm 0.02^{\mathrm{a}}$ & $4.46 \pm 0.00^{\mathrm{c}}$ \\
LB15 & $0.58 \pm 0.00^{\mathrm{d}}$ & $0.80 \pm 0.01^{\mathrm{b}}$ & $26.22 \pm 0.16^{\mathrm{c}}$ & $3.61 \pm 0.01^{\mathrm{a}}$ & $3.95 \pm 0.01^{\mathrm{d}}$ \\
LB30 & $0.55 \pm 0.01^{\mathrm{e}}$ & $0.72 \pm 0.00^{\mathrm{c}}$ & $25.42 \pm 0.12^{\mathrm{d}}$ & $3.05 \pm 0.04^{\mathrm{b}}$ & $3.49 \pm 0.01^{\mathrm{e}}$ \\
VBO & $0.68 \pm 0.01^{\mathrm{b}}$ & $0.90 \pm 0.02^{\mathrm{a}}$ & $31.93 \pm 0.21^{\mathrm{a}}$ & $2.72 \pm 0.03^{\mathrm{c}}$ & $8.46 \pm 0.00^{\mathrm{a}}$ \\
VB15 & $0.62 \pm 0.00^{\mathrm{c}}$ & $0.80 \pm 0.01^{\mathrm{b}}$ & $25.10 \pm 0.38^{\mathrm{c}}$ & $1.70 \pm 0.05^{\mathrm{d}}$ & $8.17 \pm 0.02^{\mathrm{b}}$ \\
VB30 & $0.55 \pm 0.00^{\mathrm{e}}$ & $0.73 \pm 0.00^{\mathrm{c}}$ & $25.38 \pm 0.17^{\mathrm{d}}$ & $1.20 \pm 0.02^{\mathrm{e}}$ & $8.08 \pm 0.0^{\mathrm{b}}$ \\
\hline
\end{tabular}

Values are expressed as means \pm standard deviation on a dry weight basis. Means of triplicate determinations \pm S.D.

Means with different superscripts on the same column are significantly different at $\mathrm{p} \leq 0.05$

Legends: LB0 - Locust beans cooked for 0 min, LB15 - Locust beans cooked for $15 \mathrm{~min}$, LB30 - Locust beans cooked for $30 \mathrm{~min}$,

VB0 - Velvet beans cooked for 0 min, VB15 - Velvet beans cooked for $15 \mathrm{~min}$, VB30 - Velvet beans cooked for $30 \mathrm{~min}$.

Low levels of saponins are present in the samples and there was slight reduction after cooking and fermentation. Nwaoguikpe et al., (2011) observed reduction in the concentration of saponins in velvet beans after soaking and cooking. Saponins are recently shown to have hypocholestrolemic as well as anti-carcinogenic effects. Trypsin inhibitor activity (TIA) levels of both condiments from locust beans and velvet beans reduced after cooking and fermentation. The loss in TIA content during processing can be attributed to leaching during soaking, by heat treatment during boiling and also by the action of microorganisms during fermentation Esenwah and Ikenebomeh, (2008) has also observed in the fermentation of African locust beans. There was significant $(p \leq 0.05)$ decrease in tannin level of the samples. Loss of tannin may be due to its solubility in water and its sensitivity to heat during boiling (Esenwah. and Ikenebomeh, 2008), since later report indicated that processing methods such as soaking, boiling and fermentation lowered the tannin contents of the foods which may also be due to the thermal degradation and denaturation. Since the seed coats are usually removed by soaking prior to consumption, the tannins in Mucuna beans are of little significance from the nutritional point of view (Mugendi et al., 2010). Tannins are known to possess health benefits, wherein they are 15-30 time more efficient in radical quenching activity than Trolox and other simple phenolics (Gallegos-Infante et al., 2007).

\section{Antioxidant composition of condiments from locust and velvet beans}

Figure 1and 2 shows the antioxidant properties of condiments produced from fermented locust beans and velvet beans. The total phenolic content increased as cooking time increased for all samples of fermented locust beans and velvet beans (Figure 1). It also revealed that there was decrease in total flavonoid content for fermented locust beans after $15 \mathrm{~min}$ of cooking, this later increased slightly at 30 min of cooking. The level of flavonoid in fermented velvet beans was constant at both $15 \mathrm{~min}$ and $30 \mathrm{~min}$ of cooking. The vitamin $\mathrm{C}$ content of fermented locust beans was uncovered to increase after cooking but there was decrease in the level of vitamin $\mathrm{C}$ in fermented velvet beans when subjected to cooking. It was also showed that FRAP of fermented locust beans increased slightly at 15 min of cooking. However, the level of FRAP (Ferric Reduction Antioxidant Power) of fermented velvet beans reduced steadily as cooking progressed. Reduction was observed in the level ABTS for fermented locust beans after cooking but rose slightly for fermented velvet beans after cooking for $15 \mathrm{~min}$. The free radical (DPPH) scavenging activity level of fermented locust beans was raised at $15 \mathrm{~min}$ of cooking unlike fermented velvet beans which reduced at the same cooking interval (Figure 2).

As it is made known in Figure 1, the total phenolic content (TPC) of locust beans and velvet beans increased with increase in the duration of cooking and fermentation. The increase can be attributed to duration of the cooking which enhanced diffusion of phenols from seed coats to cooking water and from there to cotyledons. According to Singleton et al., (1999) a minor amount of phenols can be explained by a lixiviation phenomenon that drives phenols into the cooking water. This process is a function of temperature (high temperature leads to an increase in lixiviation), and will promote diffusion of phenols into cotyledons. This phenomenon might have occurred in locust and velvet beans during cooking for both $15 \mathrm{~min}$ and $30 \mathrm{~min}$. Similar increase in phenols was observed after cooking of common bean (Phaseolus vulgaris L.) cultivars (Gallegos-Infante et al., 2007). The presence of high amount of phenols indicates that the condiments could act as anti-inflammatory, anti- clotting, antioxidant, immune enhancers and hormone modulators (Okwu and Omodamiro, 2005)

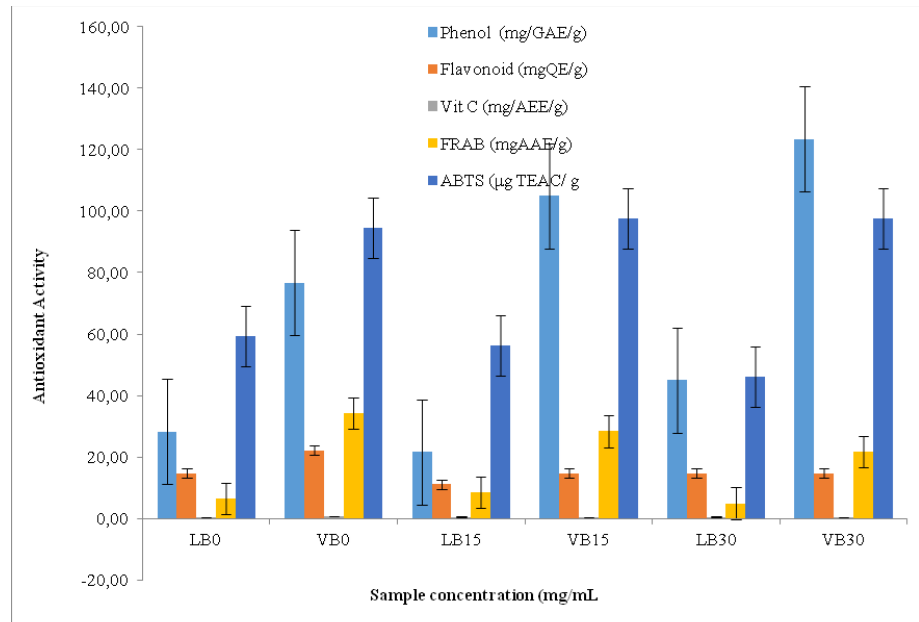

Figure 1 Antioxidant activity of condiments from locust and velvet beans fermented at $35^{\circ} \mathrm{C}$.

Legends:

LB0 - Locust beans cooked for 0 min,

LB15 - Locust beans cooked for $15 \mathrm{~min}$

LB30 - Locust beans cooked for $30 \mathrm{~min}$,

VB0 - Velvet beans cooked for $0 \mathrm{~min}$,

VB15 - Velvet beans cooked for $15 \mathrm{~min}$,

VB30 - Velvet beans cooked for $30 \mathrm{~min}$.

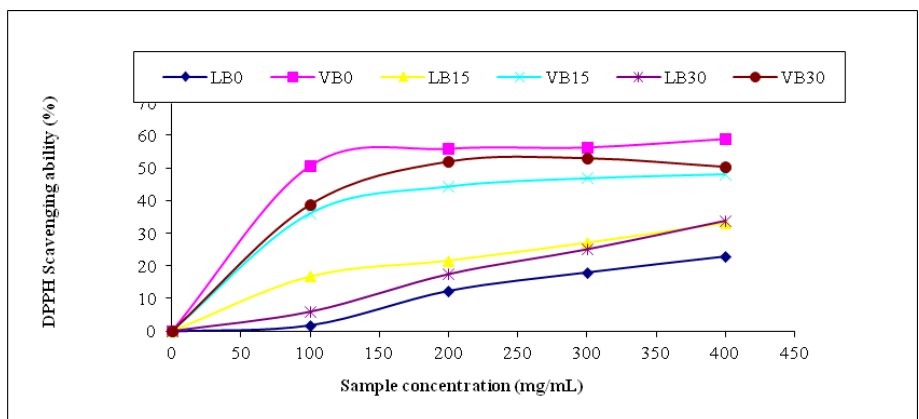

Figure 2 2, 2-diphenyl-picryl-hydrazyl (DPPH) scavenging activity of condiments from locust and velvet beans fermented at $35^{\circ} \mathrm{C}$.

Values are expressed in \% scavenging activity

Legends:

LB0 - Locust beans cooked for $0 \mathrm{~min}$,

LB15 - Locust beans cooked for 15 min,

LB30 - Locust beans cooked for $30 \mathrm{~min}$,

VB0 - Velvet beans cooked for $0 \mathrm{~min}$,

VB15 - Velvet beans cooked for $15 \mathrm{~min}$,

VB30 - Velvet beans cooked for $30 \mathrm{~min}$

There was reduction in total flavonoid content (TFC) of fermented locust beans and velvet beans as shown in Figure 1. Similar decrease in flavonoid content of locust beans was observed by Enujiugha, (2010) who studied effects of solvent extraction and heat treatment methods on phenolics components of African locust bean seeds. Notably, flavonoid concentrations were affected by cooking; this confirms the work of Gallegos-Infante et al., (2007) which reported that flavonoids are destroyed by heat processing methods like drying, roasting and boiling. Flavonoids are widely distributed group of polyphenolic compounds, 
characterized by a common benzopyrone ring structure that has been reported to act as antioxidants in various biological systems. The biological functions of flavonoids apart from its antioxidant properties include protection against allergies, inflammation, free radicals, platelet aggregation, microbes, ulcers, viruses and tumors (Okwu and Omodamiro, 2005). Flavonoids reduce cancer by interfering with estrogen synthetease, an enzyme that binds estrogen to receptors in several organs (Okwu and Omodamiro, 2005).

There was reduction in the level of vitamin $\mathrm{C}$ of both cooked, fermented locust and velvet beans as shown. The decrease in the level of vitamin $\mathrm{C}$ of cooked fermented velvet beans can be linked to oxidation and destruction of vitamin $\mathrm{C}$ during cooking. Also, high levels of phenolics in the fermented beans decrease the availability of vitamin and minerals (Mugendi et al., 2010). Vitamin C being an iron absorption enhancer is known to counteract the inhibitory effects of phytate in intestine (Siegenberg et al., 1991). Ferric Reducing Property (FRAP) assay depends on the reduction of ferric tripyridyltriazine (Fe (III)-TPTZ) complex to the ferrous tripyridyltriazine (Fe (II)-TPTZ) by a reductant (antioxidants or other reducing agents) at low $\mathrm{pH}$. As shown in Figure 4, there was reduction in FRAP of both beans as cooking progressed and this can be linked to increase in phenols which generally reduced antioxidant power of the condiments (Singleton $\boldsymbol{e t}$ al. 1999). Similar reason can be adduced to reduction in ABTS Radical Scavenging Ability after cooking as shown. The increase in phenols as cooking progressed has affected the overall anti-oxidant properties of both cooked fermented locust beans and velvet beans.

The mechanism of DPPH radical scavenging assay is based on the reduction of $\mathrm{DPPH}^{*}$ solution in the presence of a hydrogen donation antioxidant, inducing the formation of non-radical form DPPH-H (Yang et al., 2008). It is interesting to note that DPPH Radical Scavenging Activity is directly linked to the concentration of the samples, because higher levels of extracts show higher effect in free radica trapping. Figure 2 revealed higher percentage scavenging ability was detected in cooked fermented, sample which shows that at longer cooking, locust and velvet beans have high abilities for trapping free radicals. However, the fall in percentage radical scavenging ability (30 min of cooking)as also observed for soy bean oi (Jalali Mousavi et al., 2015) for both beans can be linked to diffusion of phenols to cooking water and cotyledon and the formation of complex phenol-protein, which, is not an active component to produce antioxidant effects. Similar observation was made by Gallegos-Infante et al. (2007) after analysis of scavenging ability of some cooked cultivars of common bean (Phaseolus vulgaris L).

\section{CONCLUSION}

This research work has shown that the use of Bacillus subtilis resulted in improving nutritional quality of condiments from locust beans and velvet beans. It was discovered that the condiment possessed antioxidant properties which were found to decrease due to processing methods. Also, the presence of some phytochemicals and the antioxidant properties demonstrated by fermented velvet bean and locust beans may be an indication that the legumes can be employed as functional foods.

Conflict of interest: On behalf of all authors, the corresponding author states that there is no conflict of interest on the research work.

\section{REFERENCES}

Adebowale, Y.A., Adeyemi, I.A. \& Oshodi, A.A. (2005). Variability in the physiochemical and anti-nutritional attributes of six Mucuna species. Food Chem., 89:37 - 48.https://doi.org/10.1016/j.foodchem.2004.01.084

Aderibigbe, E.Y.,Visessanguan, W.,Sumpavapol, P. \& Kongtong, K. (2011) Sourcing starter cultures for Parkia biglobosa fermentation I: Phylogenic grouping of Bacillus species from commercial 'iru' samples. Int J Biotechnol Mol Biol Res. 2(7):121-127.

AOAC. (2010). Official methods of analysis (18th ed.). Washington D.C. USA Association of Official Analytical Chemists inch.400- 2200 Wilson Boalevard, Arlinton Virginia USA 2: 910-928.

Babalola, R.O. \& Giwa, O.E. (2012). Effect of fermentation on nutritional and antinutritional properties of fermenting Soy beans and the antagonistic effect of the 103 fermenting organism on selected pathogens. Int Res J Microbiol.,3 (10): 333 338 .

Bhat, R. \& Karim, A. A. (2009). Exploring the nutritional potential of wild and underutilized legumes. Compre Rev Food Sci Food Safety, 8(4):305 331.https://doi.org/10.1111/j.1541-4337.2009.00084.x

Brunner, J. H. (1984). Direct spectrophotometric determination of saponin. Analy Chem., 34: $1314-1326$.

Bushra, S., Farooq, A. \& Muhammad, A. (2009). Effect of Extraction Solvent/Technique on the Antioxidant Activity of Selected Medicinal Plant Extracts. Mol, 14:2167 -2180. https://doi.org/10.3390/molecules14062167. PMid:19553890

Butrits, M. \& Bucar, F. (2000). Antioxidant activity of Nigeria sativa essential oil Phytother Res., 14: $323 \quad$ - 328. https://doi.org/10.1002/10991573(200008)14:5<323::AID-PTR621>3.0.CO;2-Q
Chelule, P.K., Mbongwa, H.P., Carries, S.\& Gqaleni, N. (2010). Lactic acid fermentation improves the quality of amahewu, a traditional South African maizebased porridge. Food Chem., 122 (3): 656 - 661. https://doi.org/10.1016/j.foodchem.2010.03.026

David, O.M. \& Aderibigbe, E.Y. (2010). Microbiology and proximate composition of "ogiri", pastry produced from different melon seeds. New York Sci J., 3 (4):18 $-27$.

Day, R.A. \& Underwood, A.L. (1986). Quantitative analysis. $5^{\text {th }}$ ed. Prentice-Hall publication: 701 .

Egounlety, M. (2003). Processing of velvet bean (Mucuna pruriens var utilis) by fermentation. J. Trop Subtrop Agroecosyst, 1: 173 - 181 .

Enujiugha, V.N. (2010). The antioxidant and free radical scavenging capacity of phenolics from African locust bean seeds (Parkia biglobosa). Adv Food Sci, 32 (2): $88-93$

Enujiugha, V.N., Akanbi, C.T. \& Adeniran, H.A. (2008). "Evaluation of starters for the fermentation of African oil bean (Pentaclethra macrophylla, Benth) seeds", Nutri Food Sc.i38 (5): 451 - 457.https://doi.org/10.1108/00346650810906976

Esenwah, C. N. \& Ikenebomeh, M. J. (2008). Processing effect on the nutritional and antinutritional content of African locust bean (Parkia biglobosa benth.). Pak J. Nutri.,(7) 2: 214- 217. https://doi.org/10.3923/pin.2008.214.217

Ezeagu, I.E., Maziya-Dixon, B. \& Tarawali, G. (2003). Seed characteristics and nutrient and antinutrient composition of 12 Mucuna accessions from Nigeria. $J$ Trop Subtrop Agroecosyst., 1: 129 - 140.

Fagbemi, T. (1989). Agro forestry potentials of Parkia biglobosa (Jacq) in the savanna zone of Nigeria. 'Trees for development in Sub-Saharan Africa'. Proceedings of a regional seminar held by the International Foundation for Science (IFS), ICRAF House, Nairobi, Kenya, February 20 - 25, 1989.

Gabriel, R.A.O.,Adetuyi, F.C.\& Onifade, A.K. (2004). Changes in the antinutrient content of jack beans (Canavalia ensiformis, L) subjected to liquid and solid substrate fermentation. Sci Focus, 9: 7 - 11 .

Gallegos-Infante, J.A., Rocha-Guzma'n, N.E., Gonza'lez-Laredo, R.F., IbarraPe'rez, F.J. \& Nava-Beru'men, C.A. (2007). Effect of pressure cooking on the antioxidant activity of extracts from three common bean (Phaseolus vulgaris $\mathrm{L}$.) cultivars. Food Chem.,100

35.https://doi.org/10.1016/j.foodchem.2005.09.005

Güçlü, K., Sözgen, K., Tütem, E., Özyürek, M. \& Apak, R. (2005). Spectrophotometric determination of ascorbic acid using copper (II)-neocuproine reagent in beverages and pharmaceuticals, Talanta, 65(5):1226 1232.https://doi.org/10.1016/j.talanta.2004.08.048 PMid:18969936

Guerranti, R., Aguiyi, J.C., Neri, S., Leoncini, R., Pagani, R. \& Marinello, E. (2002). Proteins from Mucuna pruriens and enzymes from Echiscari natus venom: characterization and cross-reactions. J Biol Chem., 277:17072 17078.https://doi.org/10.1074/jbc.M201387200 PMid: 11867642

Iorgyer, M.I., Adeka, I.A., Ikondo, N.D. \& Okoh, J.J. (2009). The impact of boiling periods on the proximate composition and levels of some anti nutritional factors in Pigeon pea (Cajanus cajan) seeds. J Agric Nassarawa State University, Keffi, 5(1):92-102.

Jalali Mousavi, S. R., Niazmand, R. \& Shahidi -Noghabi M.(2015). Antioxidant Activity of Purslane (Portulaca oleracea L.) Seed: Hydro-alcoholic Extract on the Stability of Soybean Oil. J. Agr. Sci. Tech. 17: 1473-1480

Josephine, M.R. \& Janardhanan, K. (1992). Studies on chemical composition and anti-nutritional factors in three germ plasm seed materials of the tribal pulse, Mucuna pruriens(L.) DC. Food Chem., 43: 13 - 18.https://doi.org/10.1016/03088146(92)90235-T

Kakade, M.L., Rackis, J.J., McGhee, J.E. \& Puski, G. (1974). Determination of trypsin inhibitor activity of soy products: a collaborative analysis of an improved procedure. Cereal Chem., 51: 376 - 382

Makkar, H.P.S. (1999) Quantification of Tannin in Tree Foliage. A Laboratory Manual for the FAO/IAEA Co-Ordinated Research Project on Use of Nuclear and Related Techniques to Develop Simple Tannin Assay for Predicting and Improving the Safety and Efficiency of Feeding Ruminants on the Tanniferous Tree Foliage Joint FAO/IAEA Division of Nuclear Techniques in Food and Agriculture, Vienna

Misra, L. \& Wagner, H. (2007). Extraction of bioactive principles from Mucuna pruriens seeds. Ind J Biochem Biophys., 44: 56 - 60.PMid:17385342

Mugendi, J.B., Ngaji, E.N., MKuria, E.N., Mwasamu, M.A., Muriethi, J.G. \& Apostolides, Z. (2010). Effects of processing techniques on the nutritional composition and anti-nutriient content of Mucuna bean (Mucuna pruriens L.). Afri J Food Sci., 4: 156 - 166.

Nout, M.J.R (1994). Fermented foods and food safety. Food Res Int., 27 (3): 291 298. https://doi.org/10.1016/0963-9969(94)90097-3

Nwaoguikpe, R.N., Braide, W. \& Ujowundu, C. O. (2011). The Effects of Processing on the Proximate and Phytochemical Compositions of Mucuna pruriens Seeds (Velvet Beans). Pak J Nutri., 10 (10): $947-$ 951.https://doi.org/10.3923/pjn.2011.947.951

Oboh, G., Puntel, R. L. \& Rocha, J. B. T. (2007). Hot pepper (Capsicum annuum, Tepin and Capsicum chinese, Habanero) prevents Fe2+-induced lipid peroxidation 116 in brain in- vitro. Food Chem., 102(1):178185.https://doi.org/10.1016/j.foodchem.2006.05.048 
Okon, E.U \& Akpanyung, E.O (2005). Nutrients and Antinutrients in selected Brands of Malt Drinks Produced in Nigeria. Pakistan Journal of Nutrition 4(5); 352-355

Okwu, D.E. \& Omodamiro, O. D. (2005). Effects of hexane extract and phytochemical content of Xylopia aethiopica and Ocimumgratis simumon the uterus of guinea pig. Bio-res., 3(2):40-44.

Oyaizu, M. (1986).Studies on products of browning reactions: antioxidative activities of products of browning reaction prepared from glucosamine. Jap J Nutri.,44: 307 - 315.https://doi.org/10.5264/eiyogakuzashi.44.307

Re, R., Pellegrini, N., Proteggente, A., Pannala, A., Yang, M. \& Rice-Evans, C. (1999). Antioxidant activity applying an improved ABTS radical cation decolorization assay.Free Rad Bio Med, 26:1231 - 1237 https://doi.org/10.1016/S0891-5849(98)00315-3

Sarkar, P.K., Cook, P.E. \& Owens, J. D. (1993). Bacillus fermentation of soybeans. World J Microbiol Biotechnol.,9: $295 \quad$ - 299 .https://doi.org/10.1007/BF00383066PMid:24420029

Siddhuraju, P., Vijayukumari, K. \& Janardhanan, K. (1996). Chemical composition and protein quality of the little-known legume, velvetbean (Mucuna pruriens) (L) (DC.). J Agric Food Chem., 44: 2636 2641.https://doi.org/10.1021/jf950776x

Singleton, V.L., Orthofer, R. \& Lamuela-Raventos, R. M. (1999). Analysis of tota phenols and other oxidation substrates and antioxidants by means of Folin Ciocalteu reagent. Meth Enzym., 299:152 - 177. https://doi.org/10.1016/S00766879(99)99017-1

Siegenberg, D., Baynes, R. D., Bothwell, T. H., Macfarlane, B. J., Lamparelli, R. D., Car, N. G., MacPhail, P., Schmidt, U., Tal. A. \& Mayet, F. (1991). Ascorbic acid prevent the dose-dependent inhibitory effect of polyphenols and phytates on non-heme iron absorption. Amer J ClinNutri., 53: 537 - 541.PMid:1989423

Yang, B., Jiang, Y. M., Zhao, M. M., Shi, J. \& Wang, L. Z. (2008). Effects of ultrasonic extraction on the physical and chemical properties of polysaccharides from longan fruit pericarp. Polymer Degrad Stab.,93, 268-272. https://doi.org/10.1016/j.polymdegradstab.2007.09.007 